\title{
PENDIDIKAN ISLAM DAN KESADARAN PLURALISME
}

\author{
Afif Syaiful Mahmudin \\ Dosen FITK IAIN Ponorogo \\ afifsyaifulmahmudin@gmail.com
}

\begin{abstract}
Abstrak
Islam menurut mayoritas pemeluknya adalah agama holistik. Islam tidak hanya diartikan sebagai agama tauhid belaka, melainkan ajaran yang menyangkut semua aspek kehidupan, agama publik, pluralisme agama tidak sekedar persoalan mengakomodasi klaim-klaim kebenaran agama dalam wilayah pribadi, tetapi juga persoalan kebijakan publik di mana pemimpin muslim harus mengakui dan melindungi kebebasan beragama, tidak hanya intra-umat Islam, tetapi antar-agama dan agama penutup yang mengajarkan ketuhanan dan kemanusiaan, termasuk di dalamnya persoalan pluralisme. Pluralisme adalah sesuatu terlahir dari dalil ajaran ketuhanan. Akal menyimpulkan bahwa jika keesaan hanya milik Allah, maka selain-Nya tidak layak untuk menyandangnya yang berarti selain Allah adalah pluralitas. Kemajemukan serta keberagaman dalam hal agama, tradisi, kesenian, kebudayaan, cara hidup, dan pandangan nilai yang di anut oleh kelompok etnis masyarakat Indonesia. Pada satu sisi, keberagaman dan kemajemukan ini bagi Indonesia bisa menjadi kekuatan yang positif dan konstruktif. Pada sisi lain, akan menjadi kekuatan yang negatif dan destruktif apabila tidak di arahkan dengan positif
\end{abstract}

Keywords: Pendidikan Islam, Pluralisme

\section{Pendahuluan}

Islam menurut mayoritas pemeluknya adalah agama holistik. Islam tidak hanya diartikan sebagai agama tauhid belaka, melainkan ajaran yang menyangkut semua aspek kehidupan, agama publik, pluralisme agama tidak sekedar persoalan mengakomodasi klaim-klaim kebenaran agama dalam wilayah pribadi, tetapi juga persoalan kebijakan publik di mana pemimpin 
muslim harus mengakui dan melindungi kebebasan beragama, tidak hanya intra-umat Islam, tetapi antar-agama dan agama penutup yang mengajarkan ketuhanan dan kemanusiaan, termasuk di dalamnya persoalan pluralisme. Pluralisme adalah sesuatu terlahir dari dalil ajaran ketuhanan. Akal menyimpulkan bahwa jika keesaan hanya milik Allah, maka selain-Nya tidak layak untuk menyandangnya yang berarti selain Allah adalah pluralitas.

Dewasa ini wacana pluralisme agama menjadi wacana yang mulai digembar-gemborkan kembali, terutama di Indonesia. Hal ini tidak terlepas seiring munculnya berbagai kekerasan yang mengatas-namakan agama. Agama dipandang sebagai sumber pemicu konflik antar umat beragama itu sendiri. Konflik semacam itu sangat mungkin terjadi bahkan intensitasnya bisa lebih tinggi jika melihat konteks Indonesia yang multi agama dan dari masing-masing agama mengajarkan bahwa dirinyalah yang paling benar sedangkan yang lain salah. Karena itulah konflik yang mengatasnamakan agama di Indonesia tergolong permasalahan yang rawan terjadi sehingga perlu adanya ajaran tentang Pluralitas Agama.

Indonesia dikenal sebagai masyarakat yang pluralistik dan menyimpan kemajemukan serta keberagaman dalam hal agama, tradisi, kesenian, kebudayaan, cara hidup, dan pandangan nilai yang di anut oleh kelompok etnis masyarakat Indonesia. Pada satu sisi, keberagaman dan kemajemukan ini bagi Indonesia bisa menjadi kekuatan yang positif dan konstruktif. Pada sisi lain, akan menjadi kekuatan yang negatif dan destruktif apabila tidak di arahkan dengan positif.

Di Indonesia, maraknya tindak kekerasan atas nama agama, ideologi, kekuasaan dan lainnya, yang terjadi akhir-akhir ini tidak dapat dilepaskan dari peranan pendidikan. Pendidikan karakter yang menekankan dimensi etisreligius menjadi relevan untuk diterapkan. Berbagai isu sosial Isu mengenai radikalisme masyarakat sudah begitu merebak hingga memunculkan pemakluman.

Hasil penelitian LaKIP (Lembaga Kajian Islam dan Perdamaian) Paramadina ikut berpartisipasi dalam kegiatan ini menunjukkan tingginya tingkat kecenderungan guru pendidikan agama Islam (PAI) dan siswa SMPSMA beragama Islam di JABODETABEK terhadap intoleransi. Kecenderungan radikalisme, kekerasan, dan intoleransi menyelimuti guru pendidikan agama Islam (PAI) dan siswa SMP-SMA di JABODETABEK.

Kecenderungan itu terungkap dalam survei Lembaga Kajian Islam dan Perdamaian (LaKIP) yang dilakukan pada Oktober 2010 hingga Januari 2011, melibatkan 590 dari total 2.639 guru PAI dan 993 siswa beragama Islam dari jumlah 611.678 murid sekolah menengah di JABODETABEK sebagai responden. Hasilnya mengagetkan. Menyangkut toleransi, misalnya, 62,7\% responden guru PAI keberatan non-muslim membangun tempat ibadah di 
lingkungan tempat tinggal mereka, sedangkan siswa yang keberatan $40,7 \%$. Saat ditanya jika non-muslim menjadi kepala sekolah, $57,2 \%$ guru dan $45,2 \%$ siswa tidak setuju. Hasil survei juga menunjukkan tingkat dukungan terhadap aksi kekerasan cukup tinggi. Begitu juga tingkat kesediaan mereka terlibat dalam aksi kekerasan terkait isu agama.

Disinilah fungsi semua jenis lembaga pendidikan dengan materi Pendidikan Agama Islam agar dapat memberikan peran maksimal bagi satu komunitasnya untuk menumbuhkan kesadaran pluralisme secara lebih luas baik di ranah Formal, non-Formal dan Informal.

\section{Pengertian Pluralisme}

Pluralisme berasal dari bahasa latin plures yang berarti "beberapa" dengan implikasi perbedaan. ${ }^{1}$ Dalam bahasa Inggris adalah pluralism berasal dari kata plural yang berarti "kemajemukan dan keragaman" dan isme berasal dari bahasa latin yang berarti paham. Secara terminologis pluralisme diartikan sebagai paham atau wacana keragaman agama. ${ }^{2}$

Diana Eck pimpinan Pluralism Project Harvard University memberikan tiga garis besar tentang pluralisme: Pertama, pluralisme adalah keterlibatan aktif (active engagement) di tengah keragaman dan perbedaan. Kedua, pluralisme lebih dari sekadar toleransi. Dalam toleransi akan lahir sebuah kesadaran tentang pentingnya "menghargai" orang lain. Tapi pluralisme meniscayakan adanya upaya untuk membangun pemahaman yang konstruktif (constructive understanding) tentang "yang lain". Ketiga, pluralisme bukanlah relativisme. Pluralisme adalah upaya untuk menemukan komitmen di antara partikularitas-partikularitas. ${ }^{3}$

Pengertian pluralisme memiliki bebeapa makna tergantung pada konteks yang dirujuknya. Diantara makna pluralisme itu:

1. Pluralisme dari sudut pandang filsafat menekankan doktrin tentang kemungkinan penyatuan pandangan universal penduduk dunia.

${ }^{1}$ Komaruddin Hidayat (ed), Passing Over Melintasi Batas Agama (Jakarta: Gramedia dan Paramadina, 1998), hlm.214

${ }^{2}$ Charles EF (ed), New Practical Standard Dictionary, Vol. A-P(New York: Funk and Wagnall Company, 1955), 1010. Menurut The Oxford English Dictionary, pluralism berarti "sebuah watak untuk menjadi plural". Lihat dalam Masykuri Abdillah, Demokrasi di Persimpangan Makna, hlm. 146.

3 Jandra, M., "Islam dalam Konteks Budaya dan Tradisi Plural," ed: Zakiyuddin Baidhawy dan Mutohharun Jinan, Agama dan Pluralitas Budaya Lokal (Surakarta: Universitas Muhammadiyah Surakarta, 2003), hlm.43. 
2. Perspektif etika dan sosiologi normatif, pluralisme etika yang tunduk pada wacana rasional dan terbuka. ${ }^{4}$

3. Pluralisme menurut kaum pragmatis menggunakan konsep pluralisme dalam sosiologi pengetahuan. Pada saat yang sama pluralisme menjadi lawan bagi aparat negara monistik, maka dalam diskusi politik, "pluralisme berarti multi partai, desentralisasi aparat Negara, atau distribusi sumberdaya kekuasaan dalam masyarakat".

4. Menurut sosiologi dan etnologi budaya, pluralisme adalah fragmentasi bahasa, agama, atau batasan lainnya.

5. Menurut sosiologi fungsional, pluralisme adalah diferensiasi masyarakat baik individual, organisasi formal, maupun masyarakat.

6. Konteks wacana ilmu sosial, pluralism adalah pengakuan terhadap keragaman dalam masyarakat dan sebagai prasyarat bagi pilihan dan kebebasan individu. ${ }^{5}$

7. Klaim pluralisme yang terangkum dalam tabel umum pengertian pluralisme adalah: kesetiaan menerima pluralitas, dorongan kebebasan termasuk kebebasan beragama, pilar demokrasi, membangun toleransi, bukan sinkretisme dan relativisme, mempunyai tempat yang sah dan berakar dalam agama Islam, mengakui keselamatan agamaagama, mendorong dialog antaragama dan antar iman, wadah konstitusional untuk pluralisme di Indonesaia adalah Pancasila. ${ }^{6}$

\section{Islam dan Pluralisme}

Perspektif Islam dalam masalah pluralisme agama terlihat jelas melalui penjabaran, pertama, dasar-dasar teoritis yang terdiri dari dasar tauhid, dasar pluralitas adalah sunnatullah, dasar kebebasan beragama, dan dasar pluralisme perlu frame of reference. Kedua, kesaksian sejarah sepanjang zaman yang meliputi zaman Rasulullah, khulafa al-Rashidin. ${ }^{7}$

${ }^{4}$ Konsep pluralisme ini awalnya dikemukakan oleh filosof pencerahan Christian Wolff dan Immanuel Kant. Meminjam terminologi Jurgen Habermas tentang pluralism etika. Lihat dalam Zakiyuddin Badhawy, Ambivalensi Agama Konflik \& Nirkekerasan (Yogyakarta: LESFI, 2002), hIm. 14.

5 Zakiyuddin Badhawy, Ambivalensi Agama Konflik \& Nirkekerasan (Yogyakarta: LESFI, 2002), hlm. 14.

${ }^{6}$ Budhy Munawar dan Rachman, Argumen Islam untuk Pluralisme(Jakarta: Grasindo, 2010), hlm. 84-90.

${ }^{7}$ Sentralitas tauhid menjadi dasar teori pluralisme dalam bagaimana Islam melihat hakikat Tuhan, hakikat wahyu, hakikat manusia, dan hakikat masyarakat. Anis Malik Thoha, Tren Pluralisme Agama Tinjauan Kritis (Jakarta: Perspektif, 2005), hlm. 180-231. 
Dalam Islam, pluralitas yang dibangun diatas tabiat asli, kecenderungan individual, dan perbedaan masing-masing pihak masuk dalam kategori fitrah yang telah digariskan oleh Allah swt bagi seluruh manusia. ${ }^{8}$

Anis Malik Thoha mengklasifikasikan tren-tren pluralisme Agama ke dalam empat kategori : Tren Humanisme Sekuler (Secular Humanism), Tren Teologi Global (Global Theology) Tren Sinkretisme (Syncretism), dan Tren Hikmah Abadi (Al-Hikmah al-Khalidah, Perennial Wisdom, Sophia Perennis . Ciri Humanisme Sekular adalah "anthroposentris" berakar dari pemikiran Protagoras (490-420 SM) seorang pemuka kaum Shopist. Dari filosof inilah ditemukan pandangan "manusia adalah satu-satunya standar bagi segala sesuatu. Upaya sistematis yang menggunakan topeng teologis dari sebuah teori baru yang sangat krusial, yang dikenal dengan teori pluralisme. Tren pemikiran teologi global ini diusung baik oleh Wilfred Cantwell Smith dan John Hick dengan mebincangkan gagasan pluralism agama dengan perlunya membangun global theology. Sinkretisme adalah suatu kecenderungan pemikiran yang berusaha mencampur dan merekonsiliasi berbagai unsure yang berbeda-beda berasal dari berbagai agama dan tradisi dalam suatu wadah yang ada (wujud aliran baru). Hikmah abadi ini berambisi dan mengklaim ingin mengembalikan agama-agama ke habitat asal-kesucian dan kesakralannya yang sempurna lagi absolute, serta ingin memperlakukan semuanya secara adil dan sama rata semuanya. ${ }^{9}$

Cecelia Lync dalam Muhammad Ali, ${ }^{10}$ mengklasifikasikan sikap teologis sehubungan dengan multikulturalisme ke dalam 5 (lima) sikap, yaitu; (1) eksklusif, (2) inklusif, (3) pluralis, (4) apologetik, ${ }^{11}$ dan (5) sinkretik.

Sementara Alwi Shihab mengingatkan pemahaman pengertian konsep pluralisme dalam empat: Pertama, pluralisme tidak hanya menunjuk kenyataan keragaman, namun yang diharapkan adalah keterlibatan aktif terhadap kemajemukan. Kedua, pluralisme dibedakan dengan kosmopolitanisme Kosmopolitanisme menunjuk kepada suatu relita keaneka ragaman agama, ras, bangsa, hidup berdampingan di suatu lokasi, namun interaksi antar penduduk, khususnya bidang agama sangat minim. Ketiga,

${ }^{8}$ Muhammad Imarah, Islam dan Pluralitas (Jakarta: Gema Insani, 1999), hlm. 31.

9 Anis Malik Thoha, Tren Pluralisme Agama Tinjauan Kritis (Jakarta: Perspektif, 2005), hlm. 109.

${ }^{10}$ Muhammad Ali, Teologi Pluralis-Multikultural Menghargai Kemajemukan Menjalin Kebersamaan (Jakarta: Penerbit Buku Kompas, 2003), hlm. 72-73.

${ }^{11}$ Apologetik adalah sikap mempertahankan doktrin ketika ditantang dari luar. Lihat dalam Muhammad Ali, Teologi Pluralis-Multikultural Menghargai Kemajemukan Menjalin Kebersamaan (Jakarta: Penerbit Buku Kompas, 2003), hlm. 73. 
pluralisme bukan relativisme. Relativisme berasumsi bahwa kebenaran atau nilai ditentukan pandangan hidup serta kerangka berpikir seseorang atau masyarakatnya. Konsekwensi dari paham ini adalah doktrin agama apa pun harus dinyatakan benar, atau dengan perkataan lain semua agama adalah samaKeempat, pluralisme adalah bukan sinkretisme. ${ }^{12}$

Pluralisme agama dapat dianalisis pada 3 (tiga) level sosial, baik makro, menengah, dan level mikro. Pada level makro, pluralisme agama menimbulkan pengakuan dan penerimaan masyarakat dalam bidang agama. Level menengah, pluralisme berimplikasi pada penerimaan keragaman organisasi keagamaan dalam unit-unit yang berkompetisi. Sedangkan pada mikro, pluralism agama adalah menimbulkan kebebasan individu untuk memilih dan mengembangkan kepercayaannya. ${ }^{13}$

Harold Coward, ${ }^{14}$ memberikan cara merespon pluralisme agama: Pertama, logika bersama. Artinya Yang Satu yang berwujud banyak, secara filosofis dan teologis, logika ini merupakan sumber realitas dan cara paling signifikan untuk menjelaskan keanekaragaman agama. Kedua, agama sebagai alat Wahyu dan doktrin agama-agama adalah jalan untuk menuju yang satu. Ketiga, pengenalan kriteria yang mengabsahkan. Yang dimaksud adalah mengenakan criteria sendiri pada agama-agama lain.

Indonesia mengembangkan kerukunan dan toleransi beragama melalui trilogi kerukunan: Pertama, kerukunan intern umat beragama. Kedua, kerukunan antar umat beragama. Ketiga, kerukunan antar penganut agama dengan pemerintah. ${ }^{15}$

Idealita dalam kehidupan kerukunan beragama masih jauh dengan fakta yang diharapkan. Hal ini dapat dianalisis dari pengakuan semua agama yang ada di Indonesia baik Islam, Protestan, Katolik, Hindu, dan Budha yang saling mengenal agama resmi bahkan terhadap aliran yang diluar resmi, dan ketika perkembangan keberagamaan resmi menunjukkan peningkatan kuantitas, dan kualitas secara signifikan terutama Islam yang pemeluknya adalah mayoritas, namun demikian dicurigai isi keberagamaan meningkat

12 Alwi Shihab, Islam Inklusif Menuju Sikap Terbuka dalam Beragama (Bandung, Mizan, 1999), hlm. 42.

13 Zakiyuddin Badhawy, Ambivalensi Agama Konflik \& Nirkekerasan (Yogyakarta: LESFI, 2002), hlm. 14.

${ }^{14}$ Harold Coward, Pluralism, Challenge to World Religion(New York, Inner Traditions International Ltd. 1995), hlm. 32-37.

${ }^{15}$ Asep Syaefullah, Merukunkan Umat Beragama Studi Pemikiran Tarmizi Taher tentang Kerukunan Umat Beragama (Jakarta, Grafindo Khazanah Ilmu, 2007), hlm. 182-183. 
namun di sisi lain berlangsungnya gejala deviansi, yakni disatu sisi kehidupan moral sangat mengkhawatirkan. ${ }^{16}$

\section{Pluralisme di Indonesia}

Perbincangan seputar isu pluralisme keagamaan di tanah air ini, lebihlebih dnegan semakin sering terjadinya kasus konflik antar anggota masyarakat yang diduga dipicu oleh unsur SARA, begitu marak. Isu pluralisme keagamaan yang berkembang, apabila kita cermati setidaknya dapat kita rangkum dalam dua poin: pertama, pentingnya mengembangkan sikap toleransi atau sikap saling menghormati dan menghargai terhadap perbedaan dalam beragama; dan kedua, perlunya pengakuan seseorang terhadap kebenaran agama lain, di luar agama yang dipeluk. Menurut sebagian pendapat, bahwa tidak ada agama yang benar secara absolute, tetapi yang ada adalah kebenaran yang relative (relativisme teologis).

Menanggapi isu pluralisme keagamaan seperti itu, harus bersikap hatihati. Terhadap isu pertama memang kita harus menerima dan mendukungnya karena dalam agama kita (Islam) juga ada ajaran ke arah sana. Hal ini dapat kita lihat misalnya dalam QS. Al-Baqarah ayat 256, yang secara tegas mengajarkan kepada kita untuk bersikap toleran dan menghormati serta menghargai pemeluk agama lain serta member kebebasan bagi mereka untuk menjalankan keagamaan sesuai dengan keyakinannya.

Sedang terhadap isu yang kedua, kita harus berhati-hati jangan begitu saja menerima gagasan semacam itu. Dalam hal ini perlu kita perhatikan pernyataan Muhaimin, yaitu bahwa klaim kebenaran bagi setiap agama adalah sangat absah adanya, karena tanpa klaim tersebut, maka agama sebagai sistem kehidupan tidak akan memiliki kekuatan simbolik yang cukup menarik bagi pengikutnya. Selain itu, agama mempunyai asumsi dasar perlunya manusia mempunyai pegangan hidup yang tidak berubah-ubah dan stabil. Karena itu setiap pemeluk suatu agama akan berusaha memposisikan diri sebagai pelaku agamanya yang loyal, memiliki personal commitment (keterikatan diri) terhadap ajaran agamanya, memiliki semangat dedikasi dan bahkan berjuang, serta rela berkurban untuk agamanya kalau memang diperlukan. $^{17}$

16 Nurdin H. Kistanto, Etika Pergaulan Sosial-Relijius dalam Masyarakat Majemuk dalam Alif Theria Wasim (Ed), Harmoni Kehidupan Beragama: Problem, Praktik \& Pendidikan (Yogyakarta: Oasis Publisher, 2005), hlm. 99-105.

17 Muhaimin, Arah Baru Pengembangan Pendidikan Islam : Pemberdayaan, Pengembangan Kurikulum hingga Redefinisi Islamisasi Pengetahuan (Bandung : Nuansa, 2003), hlm.179. 
Untuk itu, dengan kekayaan dan keragaman budaya yang termasuk didalamnya adalah agama, Indonesia tepat memiliki pilihan kebijaksanaan pluralisme agama yang mengarahkan negara kepada lima tindakan yaitu : Pertama, mengakui tiap-tiap kelompok keyakinan. Kedua, mendorong secara spesifik agar kelompok keyakinan mengamalkan nilai keimanan dan ketakwaan. Ketiga, membina agar tiap-tiap warga negara saling menghormati atas dorongan keimanannya. Keempat membuka akses partisipasi kepada kelompok keyakinan minoritas dalam ranah kekuasaan. Kelima, memberdayakan kelompok keyakinan yang tertindas. ${ }^{18}$ Pada masa orde baru pemerintah mencanangkan trilogi kerukunan yaitu kerukunan intern umat beragama, kerukunan antar umat beragama, dan kerukunan antara umat beragama dengan pemerintah. ${ }^{19}$

\section{Pendidikan Islam dan Kesadaran Pluaralisme}

Berkenaan dengan kesadaran pluralis dalam Islam sendiri visi pluralisme secara gamblang tertera dalam beberapa Ayat Al-Qur'an, misalnya:

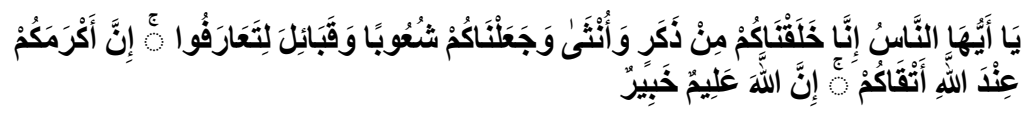

"Hai manusia, Sesungguhnya Kami menciptakan kamu dari seorang laki-laki dan seorang perempuan dan menjadikan kamu berbangsa - bangsa dan bersuku-suku supaya kamu saling kenal-mengenal. Sesungguhnya orang yang paling mulia diantara kamu disisi Allah ialah orang yang paling taqwa diantara kamu. Sesungguhnya Allah Maha mengetahui lagi Maha Mengenal". QS al-Hujurat: $13 .^{20}$

Dari ayat tersebut, Hamka dalam tafsir al-Azhar-nya menjelaskan, "Bahwasanya terjadi berbagai bangsa, berbagai suku sampai kepada perinciannya yang lebih kecil, bukanlah agar mereka bertambah lama bertambah jauh, melainkan supaya mereka kenal mengenal. Hal ini dikemukakan oleh Tuhan dalam ayat-Nya, untuk menghapus perasaan

${ }^{18}$ Ngainun Naim, Teologi Kerukunan Mencari Titik Temu Dalam Keragaman (Yogyakarta: Teras, 2011), hlm. 191.

19 Nawari Ismail, Konflik Umat Beragama Dan Budaya Lokal (Bandung: Lubuk Agung, 2011), hlm. 211.

20 Departemen Agama RI, al-Qur'an dan Terjemah, (Jakarta: Departemen Agama RI, 2002), hlm. 745. 
setengah manusia yang hendak menyatakan bahwa dirinya lebih dari yang lain, karena keturunan, bahwa dia bangsa raja, orang lain bangsa budak". ${ }^{21}$

Berdasarkan penafsiran Hamka terhadap ayat di atas dapat di ambil pemahaman bahwa, pertama Hamka dalam mengartikan tidak ada paksaan adalah sebagai ungkapan fitrah manusia. Sebab, kalau hati seseorang tulus dan ikhlas, tidak di intervensikan dari luar, maka dengan sendirinya orang akan menerima keterangan (kebenaran). Kedua ta'aruf di maknai sebagai upaya ngengakui perbedaan sebagai persaudaraan, karena pada hakekatnya manusia berasal dari keturunan yang satu, yakni Adam dan Hawa.

Dengan penafsiran seperti ini, dapat dirumuskan bahwa seseorang yang lahir kedunia secara fitrah telah memiliki hak privasi, yaitu kebebasan untuk memilih dan menentukan mana jalan yang bisa membawa kepada keselamatan. Di samping itu juga, konsep seperti ini berimplikasi bahwa ada peluang bagi PAI untuk ikut berperan dalam pengembangan individu (anak didik) untuk memebentuk sikap kedewasaan terhadap pluralitas. PAI harus menekankan pada nilai-nilai moral seperti tolong menolong, toleransi, tenggang rasa, menghormati perbedaan pendapat, dan sikap-sikap kemanusiaan lainnya. Pengkajian agama harus dilakukan atas dasar objektifitas pencarian kebenaran melalui cara-cara ilmiah. Aspek kesalah pahaman masa lalu harus dipaparkan secara seimbang tanpa harus ada pembelaan pada salah satu paham, dan juga sebaliknya.

Selanjutnya pendidikan berbasis pluralisme secara tersirat tertera pada UU Sikdiknas No.23 Tahun 2003 pasal 4 ayat 1 yang berbunyi: "Pendidikan diselenggarakan secara demokratis dan berkeadilan serta tidak diskriminatif dengan menjunjung tinggi hak asasi manusia, nilai keagamaan, nilai kultural dan kemajemukan bangsa" dan UU Sikdiknas pasal 12 ayat 1a yang berbunyi: "Peserta didik mendapatkan pendidikan agama sesuai dengan agama yang dianutnya dan diajarkan oleh pendidikan seagama".

\section{Implementasi Pendidikan Islam Berbasis Kesadaran Pluralisme Realitas Lapangan}

Pelaksanaan pendidikan agama Islam di sekolah-sekolah di Indonesia sampai sekarang diakui memang masih banyak mengandung kelemahankelemahan terutama kalau dikaitkan dengan pluralisme beragama. Haidar Baqir di dalam SKH Kompas menyatakan bahwa pendidikan agama kita tak lebih sebuah formalitas belaka, yang tidak "berbekas" pada anak didik. Pendidikan agama kita saat ini masih berpusat pada hal-hal yang bersifat simbolik, ritualistik, dan legal formal. Ada survey yang menunjukkan

${ }^{21}$ Hamka, Tafsir al-Azhar, Jus XXV-XXVI, (Jakarta: Pustaka Panjimas, Cet IV, 2003), hlm. 208. 
peningkatan signifikan dalam kesalihan-kesalihan ritual. Cara berpakaian ala Muslim (misal, memakai jilbab) mengalami perkembangan. Model dan pemakaiannya semakin terlihat lebih banyak di jalanan. Melonjaknya arus yang menunaikan haji dan umroh, dan makin tingginya laju islamisasi di berbagai bidang -termasuk makin besarnya minat orang terhadap berbagai barang konsumsi dan aksesoris yang menampilkan citra Islam, makin berkembangnya industri buku dan produk-produk informasi keislaman. Kita cenderung puas dengan mengenakan simbol-simbol keagamaan. Penghayatan keagamaan kita cenderung berpusat pada pelaksanaan ritual.

Kelemahan lain pendidikan agama adalah hanya terfokus pada ranah kognitif (intelektual-pengetahuan), sehingga ukuran keberhasilan anak didik dinilai ketika mampu menghafal, menguasai materi pendidikan, bukan bagaimana nilai-nilai pendidikan agama seperti keadilan, menghormati, tasamuh, dan silaturahim, dihayati (mencakup emosi) sungguh-sungguh dan kemudian dipraktikkan (psikomotorik). Haidar Baqir menggugat pendidikan agama yang tidak mencakup dimensi psikomotorik dan afektif. Pendidikan agama yang menekankan aspek kognitif saja mengakibatkan anak didik tidak menjadi manusia yang tawadlu', manusia yang salih secara individu dan sosial. Akibat dari pendidikan agama seperti itu sekalipun negeri ini dikatakan sebagai negeri religius, ternyata korupsinya nomor wahid. ${ }^{22}$

Hal senada dengan pendapat di atas, menurut Musa Asy'ari, realitas pendidikan agama yang diberikan di sekolah, ternyata masih bersifat doktrinal, monolog, dan dipenuhi muatan formalitas yang cenderung menolak realitas plural dalam keagamaan. Selain itu, penilaiannya cenderung bias, karena tolok ukurnya yang tidak jelas apakah pada penguasaan formal ajaran keagamaan sebagai sebuah doktrin, atau lebih lagi pada realitas kesalihan sosial sebagai manifestasi dari iman seseorang yang beragama. ${ }^{23}$

Memahami agama dengan hanya menggunakan pendekatan ini akan melahirkan sikap keberagamaan yang eksklusif, truth claim, tidak ada dialog, parsial, saling menyalahkan, saling mengkafirkan, yang dapat membentuk pengkotak-kotakkan umat, tidak ada kerjasama dan tidak terlihat adanya "kepedulian sosial". ${ }^{24}$ Sehingga yang sering ditonjolkan hanya perbedaannya, walaupun pada dasarnya masing-masing agama mempunyai perbedaan, karakter, dan ciri khas yang berbeda-beda. Sebaliknya nilai toleransi, kebersamaan, tenggang rasa, selama ini kurang ditonjolkan. Perbedaan yang ada dari keragaman agama harus bisa kita lukiskan dengan baik dalam

${ }^{22}$ Haidar Baqir, Kompas, 28 Februari 2003

${ }^{23}$ Musa Asy'ari, Dialektika Agama untuk Pembebasan Spiritual (Yogyakarta : Lesfi, 2002), hlm.86.

${ }^{24}$ Abuddin Nata, Metodologi Studi Islam, (Jakarta: Grafindo, 2000), hlm.34. 
bingkai keindonesiaan sehingga bisa menghasilkan sebuah lukisan yang indah. Tentunya dengan formula "bersaudara dalam perbedaan dan berbeda dalam persaudaraan". 25

Inilah realitas pendidikan agama kita di sekolah-sekolah yang sedang diharapkan dapat memberikan kontribusinya terhadap perdamaian dan kerukunan agama di Indonesia. Harapan ini akan mustahil apabila kita tidak mampu mengubah arah dan watak pendidikan agama kita saat ini.

\section{Pelaksanaan}

Selanjutnya, sebelum membahas tentang bagaimana menerapkan Pendidikan Islam berbasis Pluralisme, terlebih dahulu kita harus tahu tentang model-model pengembangan PAI di sekolah atau perguruan tinggi. Dalam hal terdapat tiga model yang dikemukan oleh para ahli sebagai berikut:

1. Model Dikotomi, pada model ini, aspek kehidupan dipandang dengan sangat sederhana. Segala hal yang ada hanya dipandang dari dua sisi, seperti laki-laki dan perempuan, ada dan tidak ada, pendidikan agama dan non agama dan lain sebagainya. Pandangan ini akan berimplikasi pada pengembangan ukhrowi saja, pendidikan yang bersifat duinawi tidaklah penting. Model ini berkembang pada periode pertengahan dalam sejarah pendidikan Islam.

2. Model Mekanisme, model ini memamdang kehidupan dari berbagai aspek, dan pendidikan dipandang sebagai penanaman dan pengembangan seperangkat nilai-nilai kehidupan yang terdiri atas nilai agama, nilai individu, nilai sosial, nilai politik, nilai ekonomi dan nilainilai yang lain. Model tersebut dikembangkan pada sekolah atau PT yang bukan berciri khas agama Islam, namun mungajarkan mata pelajaran atau mata kuliah agama Islam.

3. Model Sistemik, dalam konteks ini pendidikan Islam dipandang sebagai aktifitas yang terdiri atas komponen-komponen yang hidup bersama dan bekerja sama dengan tujuan tertentu, yaitu terwujudnya hidup yang religius. Model ini diterapkan oleh madrasah atau sekolah swasta Islam unggulan. ${ }^{26}$

Dalam pendidikan, semua aspek kelembagaan dan proses belajar mengajarnya harus menerapkan sistem dan metode yang dapat menyembuhkan pluralisme serta mampu menggali sisi perdamaian dan toleransi. Oleh karenanya, di antara langkah yang di tempuh guru atau dosen,

${ }^{25}$ Ahmad Syafii Ma'arif, Masa Depan Bangsa Dalam Taruhan, (Yogyakarta, Pustaka SM, 2000), hlm. 78.

26 Muhaimin, Rekonstruksi Pendidikan Islam, (Jakarta: Raja Grafindo Persada, 2009), hlm. 59-68. 
khususnya yang terkait dengan organisasi atau kegiatan pembelajaran di kelas adalah penentuan pendekatan dan metode. Hal tersebut merupakan elemen penting dalam proses belajar mengajar. Berhasil dan tidaknya suatu tujuan pendidikan tergantung pendekatan dan metode yang digunakannya. Tidak relevannya pendekatan dan metode yang di kembangkan dalam pembelajaran pendidikan agama berbasis pluralisme seperti ini perlu di perhatikan adanya beberapa pendekatan yang dapat di gunakan antara lain:

1. Pembiasaan, melaksanakan pembelajaran dengan membiasakan sikap dan perilaku yang baik, terutama sekali yang berhubungan dengan nilai seperti: tenggang rasa, toleransi, saling mengasihi, tolong menolong dan sebagainya.

2. Rasional, pendekatan yang memfungsikan rasio peserta didik, sehingga isi dan nilai yang di tanamkan mudah di pahami dengan penalaran. Disisi lain pendekatan akademis cenderung menempatkan proses pendidikan agama pada orientasi objektif.

3. Emosional, upaya menggugah perasaan peserta didik dalam memahami realitas keanekaragaman budaya dan agama dalam masyarakat. Sehingga lebih terkesan dalam jiwa peserta didik untuk selalu menampilkan sikap tenggang rasa dan saling menghormati antara agama satu dengan yang lainnya.

4. Fungsional, memfungsikan ajaran masing-masing agama (termasuk agama Islam) terutama tentang pentingnya menghargai perbedaan dengan menekankan segi manfaat dan hikmahnya bagi peserta didik dalam kehidupan sehari-hari dengan tingkat perkembangannya. ${ }^{27}$

Selanjutnya ditataran sekolah peran guru dalam kesadaran pluralisme sangat besar, karena perannya sebagai remote control dalam mengarahkan pendidikan kepada peserta didiknya, maka dalam hal internalisasi nilai pluralisme seorang guru khususnya guru pendidikan agama Islam harus bisa paham dengan benar dan baik apa yang semestinya ia lakukan. Oleh karena itu, ada beberapa alternatif model pembelajaran (pendidikan agama Islam) yang mestinya dilakukan oleh para guru mata pelajaran agama Islam sekarang ini supaya bisa menghasilkan out-put pendidikan yang inklusif, berwawasan pluralis, dan apresiatif terhadap perbedaan.

Pertama : membentuk pola pikir siswa secara terbuka untuk bersedia memeberikan kesempatan kepada orang lain untuk meyakini kebenaran agama yang mereka anut, diluar keyakinannya. Oleh karena itu, kita harus menghindari penyampaian pesan-pesan Islam secara ideologis, doktrinal yang akan mengedepankan truth claim dalam beragama. Kita harus

27 Samsyul Ma'arif, The Baeuty of Islam "Dalam Cinta dan Pendidikan Pluralisme ... hlm. 104-106 
menyampaikan pula kepada peserta didik bahwa di luar paham kita ada paham lain yang tidak mustahil mengandung kebenaran dan diyakini oleh pengikutnya. Dengan demikian, diharapkan siswa akan lebih mudah bergaul dan berinteraksi dengan orang lain, yang berbeda agama, ras, dan etnis.

Kedua, membentuk pola pikir siswa untuk bisa menghargai perbedaan secara tulus, komunikatif, inklusif, dan tidak saling curiga, di samping meningkatkan iman dan taqwa. Oleh karena itu, kita harus menghindari penyampaian pemahaman Islam yang hanya bertumpu pada tekstual normatif. Sudah saatnya siswa harus mengkaji model-model pemahaman Islam, dan mengkontekstualisasikannya dalam kehidupan nyata agar dapat menghasilkan cara pandang yang utuh dan apresiatif terhadap perubahan dan perkembangan zaman yang pluralistik dan komprehensif, yakni dengan pendekatan filosofis dan historis. ${ }^{28}$

Ketiga, para pendidik dalam menyampaikan materi pendidikan harus secara jujur, transparan serta membuang subjektifisme sejarah dan kepentingan pribadi. Sehingga materi pendidikan Islam bisa dipahami oleh peserta didik dalam kehidupan praksis. Pendidik jangan memosisikan diri sebagai "agen/penyalur" madzhab tertentu dengan menyalahkan madzhab yang lain. Dalam hal ini, sangat diperlukan tenaga pendidik yang mampu menerjemahkan pesan-pesan universal keagamaan dengan baik, dan harus mampu menegakkan demokrasi yang mengakomodasi perbedaan.

Keempat, para pendidik haruslah memahami bahwa pendidikan bukanlah sekedar transfer informasi tentang ilmu pengetahuan dari guru kepada murid, melainkan suatu proses pembentukan karakter. Dalam hal ini ada tiga misi pendidikan yaitu Transfer of knowledge (Pewarisan Pengetahuan), Transfer of culture (Pewarisan Budaya) dan Transfer of value (pewarisan nilai). Dengan demikian, dalam pendidikan Islam, kompetensi kognitif, afektif, dan psikomotor harus benar-benar menyatu dan terwujud dalam kehidupan peserta didik. Oleh karena itu, peserta didik jangan hanya diindoktrinasi tentang kesalehan vertikal/ individual, tetapi juga kesalehan sosial. ${ }^{29}$

Kelima, para pendidik perlu membiasakan anak-anak mengalami pertukaran budaya (cross cultural exchange) dengan sesama peserta didik. Pengalaman ini akan dapat membantu mereka untuk memahami orang lain dalam sebuah perbedaan. Dengan demikian, persatuan dan kesatuan pada akhirnya akan menjadi keinginan yang kuat di kalangan mereka. Kedamaian

${ }^{28}$ Komaruddin Hidayat, 2004, Menafsirkan Kehendak Tuhan, (Jakarta:Teraju, 1998), hlm. 34.

${ }^{29}$ Buchari Alma, Moral dan Kognisi Islam (Bandung: Alfabeta, 2006), hlm.2. 
yang senatiasa kita nanti-nantikan akan menjadi kenyataan sesuai dengan peran agama yang membawa pesan perdamaian bagi umat manusia.

Dengan beberapa point diatas penulis berharap dengan keyakinan bahwa pendidikan (Islam) akan mampu membawa angin segar dalam peradan yang lebih baik serta mampu menampilkan wajah islam yang inklusif, pluralis, dan apresiatif terhadap perbedaan.

\section{Contoh Penanaman PAI dalam Kesadaran Pluralisme}

Penanaman Nilai Religius, dengan metode ceramah ini digunakan dalam semua materi pelajaran pendidikan agama Islam, dan untuk metode pluralisme agama seperti pada materi Meyakini Kitab Allah, mencintai AlQur'an, guru menjelaskan bahwa semua kitab yang ada di bumi ini adalah kitab Allah termasuk kitab injil, akan tetapi kitab Allah yang paling sempurna dan yang terakhir kalinya adalah kitab Al-Qur'an, jadi kita diwajibkan lebih mencintai Al-Qur'an dan menghormati kitab agama lain. Dengan diskusi, dalam materi meneladani kemuliaan, kejujuran para Rasul Allah siswa diberikan pemahaman bahwa perilaku kita adalah Al-Qur'an dan Sunnah, didalam Al-Qur'an dan Sunnah terdapat cara kita berhubungan dengan agama Lain. Pengalaman lapangan, seperti menyembelih hewan qurban, sholat berjama'ah dan sebagainya. Hal ini penting untuk menanamkan nilai religius siswa, serta memperkuat materi pembelajaran.Sehingga siswa memahami aqidah agama siswa sendiri, serta menguatkan pengetahuan siswa dan mengajarkan siswa dapat menghormati perayaan ibadah agama lain.

Penanaman Nilai Demokrasi, metode ceramah, Guru dapat menjelaskan jika didalam Islam terdapat makanan halal dan haram, yang halal seperti daging ayam, telur, susu sapi, sayuran, ikan, dll. Dan yang haram diantararanya daging babi. Ketika bergaul dengan agama lain, kita juga harus memahami bahwa diagama lain juga ada makanan halal dan haram, seperti di agama Hindu sapi dilarang dibunuh apalagi dimakan. Sehingga dengan metode ini diharapkan para siswa muslim saat bertemu dengan siswa nonmuslim dapat menghormati.

Penanaman Nilai Toleransi, bisa diterapkan dalam materi rendah hati, hemat, sederhana membuat hidup lebih mulia, Ibadah Puasa membentuk pribadi yang bertakwa, Pertumbuhan IImu pengetahuan pada masa Abbasiyah didalam materi-materi tersebut guru menyelipkan materi-materi tentang toleransi seperti menjelaskan bahwa didalam agama lain juga terdapat puasa, seperti teman agama lain menghormati puasa Islam, kita juga harus menghormati puasa agama lain. Selaian itu didalam materi hidup sehat dengan makanan dan minuman yang begizi dapat di jelaskan kepada siswa, bergizi juga tidak harus mahal dan jika dikaitkan dengan tolerensi yaitu 
ketika kita kedatangan tamu muslim atau non muslim seharusnya kita suguhi dengan makanan yang sehat dan bergizi, jangan malah tidak dibukakan pintu hanya karena beda agama.

Penanaman Nilai Kerjasama, dalam materi pertumbuhan ilmu pengetahuan pada masa Abbasiyah guru menjelaskan bahwa ada hadis Nabi tuntutlah ilmu sampai negeri China, nah disitu dapat diambil hikmah bahwa Nabi Muhammad menginginkan kerjasama bidang ilmu pengetahuan dengan negeri yang maju, dengan Negara China dimana negara China bukanlah negara muslim tetapi negara komunis. Sehingga dengan ini diketahui pada dasarnya Islam bukan anti dengan non-Islam, akan tetapi justru malah ingin menjalin kerjasama demi kemajuan Islam.

Metode Pembelajaran Aktif, dalam metode pembelajaran ini siswa diajak secara aktif untuk melaksanakan kerjasama bersama orang lain tanpa memandang orang lain beragama apa, bersuku apa, berasal dari pulau apa, berkerjasama untuk kemajuan bersama. Guru agama dapat menjelaskan bahwa Allah dapat menciptakan manusia dalam satu jenis saja, tapi ternyata manusia tidak diciptakan hanya dalam satu jenis tetepi berbagai macam ada yang pendek-tinggi, ada yang hitam-putih, ada yang mata sipit-belo, ada yang tinggal di Indonesia ada yang tinggal di Kutub, ada yang Islam ada yang nonIslam. perbedaan-perbedaan itu hendaknya harus disyukuri, bahkan bekerjasama untuk saling melengkapi. ${ }^{30}$

\section{Penutup}

Realitas pendidikan Agama Islam di sekolah-sekolah dan perguruan tinggi belum maksimal dalam menanamkan kesadaran pluralisme. Perlu adanya perubahan disegala titik dalam pelaksanaan Pendidikan Agama Islam yang sama sekali belum menyentuh unsur pluralisme, sekaligus menyempurnakan bagi lembaga-lembaga yang sudah berjalan dalam mengimplementasikannya. Dengan ini, diharapkan Penanaman kesadaran Pluralisme melalui PAI dapat memberikan kontribusi terhadap perdamaian dan kerukunan agama di Indonesia yang notabene tergolong Negara yang plural dan majemuk.

\section{Daftar Rujukan}

Ali, Muhammad, Teologi Pluralis-Multikultural Menghargai Kemajemukan Menjalin Kebersamaan, Jakarta: Penerbit Buku Kompas, 2003.

Alma, Buchari, Moral dan Kognisi Islam. Bandung: Alfabeta, 2006.

30 Nur Rohmah Hayati, Implementasi Pendidikan Agama (Islam, Kristen, Budha) Tentang pluralisme agama di SMP N 17 Purworejo, Thesis (Jogjakarta: UIN SUKA, 2015), hlm.77-95 
Asy'ari, Musa, Dialektika Agama untuk Pembebasan Spiritual, Yogyakarta : Lesfi, 2002.

Badhawy, Zakiyuddin, Ambivalensi Agama Konflik \& Nirkekerasan. Yogyakarta: LESFI, 2002.

Badhawy, Zakiyuddin, Ambivalensi Agama Konflik \& Nirkekerasan, Yogyakarta: LESFI, 2002.

Baqir, Haidar Kompas, 28 Februari 2003.

Charles EF (ed), "New Practical Standard Dictionary", Vol. A-P. New York: Funk and Wagnall Company, 1955.

Coward, Harold, Pluralism, Challenge to World Religion, New York: Inner Traditions International Ltd, 1995.

Departemen Agama RI, al-Qur'an dan Terjemah, Jakarta: Departemen Agama RI, 2002.

Hamka, Tafsir al-Azhar, Jus XXV-XXVI. Jakarta: Pustaka Panjimas, Cet IV, 2003. Hayati, Nur Rohmah, "Implementasi Pendidikan Agama (Islam, Kristen, Budha) Tentang pluralisme agama di SMP N 17 Purworejo", Thesis. Jogjakarta: UIN SUKA, 2015.

Hidayat, Komaruddin (ed)., Passing Over Melintasi Batas Agama, Jakarta: Gramedia dan Paramadina, 1998.

Hidayat, Komaruddin, Menafsirkan Kehendak Tuhan. Jakarta:Teraju, 1998.

Imarah, Muhammad, Islam dan Pluralitas, Jakarta: Gema Insani, 1999.

Ismail, Nawari, Konflik Umat Beragama Dan Budaya Lokal, Bandung: Lubuk Agung, 2011.

Jandra, M., "Islam dalam Konteks Budaya dan Tradisi Plural," ed: Zakiyuddin Baidhawy dan Mutohharun Jinan, Agama dan Pluralitas Budaya Lokal. Surakarta: Universitas Muhammadiyah Surakarta, 2003.

Kistanto, Nurdin H., Etika Pergaulan Sosial-Relijius dalam Masyarakat Majemuk dalam Alif Theria Wasim (Ed), Harmoni Kehidupan Beragama: Problem, Praktik \& Pendidikan, Yogyakarta: Oasis Publisher, 2005.

Ma'arif, Ahmad Syafii, Masa Depan Bangsa Dalam Taruhan, Yogyakarta: Pustaka, 2000.

Ma'arif, Samsyul, The Baeuty of Islam "Dalam Cinta dan Pendidikan Pluralisme. 
Mahfud, Moh. Md. Dkk., Kritik sosial Dalam Wacana Pembangunan, Yogyakarta: UII Press, 1997.

Media Indonesia, 27 Februari 2011

Muhaimin, Arah Baru Pengembangan Pendidikan Islam : Pemberdayaan, Pengembangan Kurikulum hingga Redefinisi Islamisasi Pengetahuan, Bandung : Nuansa, 2003.

Muhaimin, Rekonstruksi Pendidikan Islam, Jakarta: Raja Grafindo Persada, 2009.

Naim, Ngainun, Teologi Kerukunan Mencari Titik Temu Dalam Keragaman, Yogyakarta: Teras, 2011.

Nata, Abuddin MA, Metodologi Studi Islam, Jakarta: Grafindo, 2000.

Quantum, Menyempurnakan Pendidikan Pluralisme, Semarang: LPM EDUKASI, 2011.

Rachman, Budhy Munawar, Argumen Islam untuk Pluralisme, Jakarta: Grasindo, 2010.

Shihab, Alwi, Islam Inklusif Menuju Sikap Terbuka dalam Beragama, Bandung: Mizan, 1999.

Syaefullah, Asep, Merukunkan Umat Beragama Studi Pemikiran Tarmizi Taher tentang Kerukunan Umat Beragama. Jakarta, Grafindo Khazanah Ilmu, 2007.

Thoha, Anis Malik, Tren Pluralisme Agama Tinjauan Kritis, Jakarta: Perspektif, 2005. 